\title{
Disturbing the Peace of "Two Not So Very Different" Countries: James Baldwin and Fritz Raddatz
}

Gianna Zocco University of Vienna

\begin{abstract}
When James Baldwin in No Name in the Street discusses the case of Tony Maynard, who had been imprisoned in Hamburg in 1967, he emphasizes that his efforts to aid his unjustly imprisoned friend were greatly supported by his German publishing house Rowohlt and, in particular, by his then-editor Fritz Raddatz (1931-2015). While the passages on Maynard remain the only instance in Baldwin's published writings in which Raddatz-praised as a courageous "anti-Nazi German" and a kindred ally who "knows what it means to be beaten in prison"-is mentioned directly, the relation between Baldwin and Raddatz has left traces that cover over fifty years. The African-American writer and Rowohlt's chief editor got to know each other around 1963, when Baldwin was first published in Germany. They exchanged letters between 1965 and 1984, and many of Raddatz's critical writings from different periods-the first piece from 1965, the last from 2014-focus on Baldwin's books. They also collaborated on various projects-among them a long interview and Baldwin's review of Roots-which were all published in the German weekly newspaper Die Zeit, where Raddatz served as head of the literary and arts sections from 1977 to 1985 . Drawing on published and unpublished writings of both men, this article provides a discussion of the most significant facets of this under-explored relationship and its literary achievements. Thereby, it sheds new light on two central questions of recent Baldwin scholarship: first, the circumstances of production and formation crucial to Baldwin's writings of the 1970s and 1980s, and secondly, Baldwin's international activities, his transcultural reception and influence.
\end{abstract}

Keywords: James Baldwin, Fritz Raddatz, No Name in the Street, Tony Maynard, Germany, Rowohlt, African-American literature

James Baldwin Review, Volume 3, 2017 @ The Authors. Published by Manchester University Press and The University of Manchester Library 
When I first read the news that Fritz J. Raddatz (1931-2015), a German journalist, writer, and editor, had committed legally assisted suicide in Switzerland, it felt like a strange coincidence that I had just stumbled over his name in a seemingly unrelated context. In No Name in the Street (1972), James Baldwin introduces himmisspelling his name as "Raddadtz"-as his German editor, and he emphasizes how "Fritz" had been his aide during the imprisonment of Baldwin's former secretary Tony Maynard in Hamburg. ${ }^{1}$ Initial brief research on Baldwin, Raddatz, and the after-effects of their joint experience with the German prison system revealed a number of traces dating from different places and periods. Whereas Baldwin scholars such as D. Quentin Miller and Magdalena Zaborowska have recently highlighted the influential role of the Maynard experience for Baldwin's writings of the 1970s and 1980s as well as for a general shift in his work to a more globally oriented "astute critique of transatlantic systems of oppression," Raddatz's large journalistic, autobiographical, and fictional oeuvre is full of references to Baldwin. ${ }^{2}$ Already in 1965 , he was the author of one of the first extensive pieces on Baldwin written in German; in 1978, Raddatz conducted a detailed interview with Baldwin for the weekly newspaper Die Zeit; and he frequently mentions him in his autobiography and in the two volumes of his published diaries. ${ }^{3}$ Even in summer 2014, just a month before Raddatz publicly announced his retirement from journalism and seven months before his death, he used the occasion of Baldwin's ninetieth birthday to write yet another piece on him for Die Zeit, once again praising Baldwin's ability to provide a sharp X-ray of American society and remembering their joint dinners during Baldwin's visits to Hamburg. ${ }^{4}$

With these facts at hand, my curiosity was definitely caught. Based on several months reading through fictional and autobiographical, public and private, published and unpublished material located in Germany and the United States, this article aims to present the findings of my research on two men who-although originating from different cultural backgrounds-were connected by an intense and lasting feeling of kinship. I will begin with a presentation of Raddatz's biography that - as anyone familiar with the main experiences and struggles of Baldwin's life will easily recognize-bears a number of similarities with the AfricanAmerican writer. I will then give an overview of the main facts of their contact and collaboration followed by an analysis of two of the most interesting aspects of this relationship-first, the reception of Baldwin's works in Raddatz's journalistic writings, and secondly, Baldwin's experiences with Raddatz and Germany during the Maynard case. I will close with some reflections on what may have been the basis for the connection between them: a shared commitment to being "disturbers of the peace", or-as Raddatz puts it in the title of his autobiography-of operating as "Unruhestifter."

\section{Fritz J. Raddatz}

By describing Raddatz as both "an anti-Nazi German, who has the scars to prove it" and as someone who "knows what it means to be beaten in prison," Baldwin in 
No Name in the Street gives a few glimpses of what he may have considered central elements of Raddatz's background. ${ }^{6}$ While the following paragraphs will try to illuminate the biographical facts that justify describing Raddatz in these terms, it seems important to note that Baldwin's phrases already provide an indication of what may have been the basis of the connection between them: from an early age, their lives did not lack in hurtful experiences of violence and memorable confrontations with what Miller called the "criminal power" of the law. ${ }^{7}$

Born in 1931 in Berlin, Raddatz was the son of a French mother who died during childbirth. Although his mother was married at the time, young Raddatz was the offspring of an affair. He grew up with his biological father-a former military officer in the German Imperial Army-an elder sister, and several "stepmothers" in Nazi Berlin. ${ }^{8}$ Maybe because he shared Baldwin's fate of being a "bastard," Raddatz remembers his childhood as characterized by violence and lack of warmth: "I was rather sharpened than educated," as he puts it in his autobiography. ${ }^{9}$ His description of an aggressive father evokes comparisons not only with Baldwin's own harsh stepfather, but also with the violent and self-deceptive white American men of Baldwin's fictional writings. Similar to the tendencies of David-from Giovanni's Room-and Jesse-from "Going to Meet the Man"-to repress seemingly immoral sexual desires through brutality, Raddatz explicitly notes in his autobiography that he later began to wonder if his father's violence and strict adherence to Prussian virtues had something to do with sexuality, and he even remembers a traumatic experience from his childhood: One night, his father entered the 11-year-old's bedroom naked and forced him to accompany him to the master bedroom and have sex with his stepmother. ${ }^{10}$

The course of Raddatz's life changed with the end of the Second World War and the terminal illness of his father. He remembers the immediate postwar period as marked by a complicated situation: "I needed to look after a dying person andlook for a living person."11 Eventually, 15-year-old Raddatz succeeded in both tasks. He managed to provide food through his friendship with African-American G.I.s, and he found himself a new legal guardian: his religious education teacher Hans-Joachim Mund. This 30-year-old Protestant priest became one of the most important people of Raddatz's life-and many aspects of their relationship read as if they were part of a Baldwin novel. To articulate what fascinated him about this man, Raddatz uses an almost Baldwinian phrase: he describes him as "an allurement of ambiguity." 12 Mund, who Raddatz described as being a priest without looking like one, had been a member of the oppositional Bekennende Kirche; he was a deserter from the army and a socialist who discussed Dostoyevsky, Jesus, and sexuality with Raddatz and his classmates; he was a husband and father-but he was also, in Raddatz's words, a bisexual adulterer, someone who had written an unfinished dissertation on the Christian concept of marriage while cheating on his wife with men throughout his life. ${ }^{13}$ For young Raddatz, his legal guardian was "the first man I loved. The love lasted for seventeen years." 14 And its nature was, as he said in an interview, by no means merely spiritual: 
[question] Your guardian-a, as you put it in your diaries, "dishonest charismatic" full of "buzzing, witch-like charm"-led a double life. Officially, he behaved as the deeply religious husband and father, while he was having sex with you, his initially minor ward, for seventeen years.

[answer] Not uncommonly behind the altar, while his wife was preparing food, which we naturally did not eat without praying beforehand. Apart from the mentioned exception [the forced sexual episode with his stepmother], I had no sexual experiences at this time and I considered our relationship as love-which it surely was from my side and, I think, from his as well. It was not merely the story of seduction between a 30 -year-old and a 15 -year-old. ${ }^{15}$

Influenced by Mund, who had been an early member of the Socialist Unity Party, Raddatz grew increasingly critical of the continuities between Nazi Germany and the Federal Republic, and he came to view the system of the newly founded GDR as more fitting to his antifascist attitudes. Following his guardian, he moved to East Berlin in 1950, where Mund occupied the position of prison chaplain for political convicts, and where Raddatz began to study humanities and was hired by the GDR publishing house Volk und Welt. However, political developments in the GDR soon began to influence what might otherwise have been the beginning of a promising editorial career. Increased difficulties with the authorities, exhausting struggles for publication permissions, frequent interrogations and threats by the Ministry of State Security, and-finally-the imprisonment of several colleagues and-maybe-his own brief incarceration made Raddatz-by now deputy chief editor of Volk und Welt-decide to flee the "criminal power" of the state he had once considered more humane, and to move back to West Germany in $1958 .{ }^{16}$

In West Germany, Raddatz soon accepted a position at Rowohlt, a publishing house with a developing reputation built on introducing major modernist writers such as Sartre, Camus, Faulkner, and Hemingway to German readers. At Rowohlt, Raddatz came to occupy the position of chief editor and deputy publishing manager, and he later considered his decade of working there as "the most important, the most beautiful, the richest of my whole life." 17 According to Raddatz, he-rather than publishing manager Heinrich Maria Ledig-Rowohltwas the one in charge of attracting and keeping in touch with major Rowohlt writers such as James Baldwin, Hubert Fichte, and Alberto Moravia, and he remembers how his publication decisions were driven by his "idea of the responsibility of the writer" and his conviction that it was important to demand "over and over again in a quite stiff-necked and tenacious manner the need to confess to German guilt." 18 While the audacity of Raddatz's editorial decisions was an important factor in promoting a more truthful public discussion about the events of recent German history, his insubordinate nature also created difficulties within Rowohlt's management. In 1969, these tensions culminated when it came to the so-called "balloon affair," an unfortunate public scandal in the course of which Raddatz was forced to resign. ${ }^{19}$ Disillusioned, he compared his experiences in East and West German publishing houses in his autobiography: "In the East, you're incarcerated, in the West, you're ejected." 20 
After these unfortunate events, Raddatz spent the following years working as a freelance writer and journalist-still relatively successful, but also suffering from the diminishment of influence and public recognition. ${ }^{21}$ In 1977, he was offered a position that he saw as a second chance to continue the work started at Rowohlt: he became head of the literary and arts sections of the influential weekly newspaper Die Zeit. Drawing on his contacts with many writers, he understood his new position as "a continuation of the publishing house with different means." ${ }^{2}$ Accordingly, he arranged a feuilleton - the German term for an "arts" sectionthat was partly written by these major intellectuals and that remained true to his convictions from the Rowohlt years. Raddatz continued to promote the publication of politically subversive and intellectually challenging texts, and he did not resist taking risks to get new "scars to prove" his antifascist convictions.

Hardly surprisingly, new conflicts were not long in coming at Die Zeit. While Raddatz's noncompliant nature continued to be a frequent cause of tensions, it was again a minor affair - this time connected to him quoting Goethe wronglythat forced him to resign in 1985. However, Raddatz continued to be a cultural correspondent and contributor for Die Zeit and other periodicals almost until his death. Yet it was not his journalistic writing that brought him most public attention during these years. When he finally published his autobiography Unruhestifter (2003) and then, in 2010 and 2014, the two volumes of his edited diaries, he received a previously unexperienced amount of recognition and partly voyeuristic interest. ${ }^{23}$ His diaries were praised as "the great social novel of the Federal Republic" and as "an almost unbearable work of art that holds a mirror up to a past epoch." ${ }^{24}$ Reading them, it is possible to observe not only Raddatz's constant need for a public recognition he never felt he received, but also to witness how the loudness and rebelliousness of his public persona corresponded to his private longing for love and intimacy. In his autobiography, he states: "I lived, as the classic calls it, 'lonely, but not alone' in that at times morbid, at times amusing, at times repugnant carousel that men who love both women and men experience." 25 Yet the final decades of his life were marked by private steadiness. After living through the early deaths of several romantic partners, Raddatz spent the last thirty years of his life in a relationship with his partner Gerd Bruns-Raddatz.

\section{Where, When, What-Facts}

I have not been able to establish the precise date when Baldwin and Raddatz first got to know each other, but it must have been in the early years of Raddatz's position at Rowohlt, presumably shortly before the first German editions of Baldwin's books were published in $1963 .{ }^{26}$ As long as Raddatz operated as Baldwin's enthusiastic German editor, their relationship had a strong professional component. Between 1960 and 1969, Raddatz was involved in, and often primarily responsible for, all major decisions concerning the quite successful publication and promotion of Baldwin's works in the German-speaking region, including the choice of translators, the organization of a lecture tour, communication with theaters 
interested in performing his plays, etc. The letters that they exchanged during this period depict both the professional component of their relationship, as well as the development of an affectionate friendship. ${ }^{27}$ Of the letters written by Baldwin, only some have a mainly professional purpose, while others include topics beyond the range of the typical questions discussed by an author and his foreign editor. For example, Baldwin repeatedly expresses his desire to spend time with Raddatz, he muses how writing to Raddatz helps him deal with his feelings of fear and panic, he consoles him on what may have been the suicide of Raddatz's romantic partner, and he reflects on what it means to lose a friend. ${ }^{28}$ Overall, these letters confirm the impression of biographer David Leeming, who remembered that "Baldwin spoke highly of Raddatz. They did meet in Germany while Jimmy was there touring with the Amen Corner and they did correspond."29

When considering Raddatz's published writings of the period, it becomes clear that this appreciation went both ways. In addition to reflections on his professional involvement with Baldwin, Raddatz's diaries include numerous anecdotal recollections of their meetings, many of which took place at glamorous parties in major European cities. But Raddatz was not merely attracted by the intellectual glamour and expatriate internationality that Baldwin may have embodied. Although he clearly enjoys depicting in great detail the dramatic quality of many of their meetings-for example, a dinner party where the German writer Uwe Johnson quarreled with Baldwin and then beat up Ledig-Rowohlt's wife, who had joined in his defense; "the night of [Ingeborg] Bachmann's useless infatuation with gay Baldwin, who begged me to get him away from her"- his involvement and fascination with Baldwin went much deeper. ${ }^{30}$ In 1965, he wrote an elaborate eight-page essay on Baldwin's work that argues for his international relevance.

When Baldwin's former secretary and chauffeur Tony Maynard was imprisoned in Hamburg in the fall of 1967, contact between Baldwin and Raddatz further intensified. In addition to what we know from No Name, several letters and telegrams held by the German literary archive in Marbach allow us to get an impression of their collaboration during the six months preceding Maynard's extradition to the US in March of 1968. From these letters it becomes clear that Raddatz was Baldwin's main contact with the German side of events. Baldwin could not only count on his support when he visited Maynard in his German prison, but he also turned to Raddatz as a trusted aide for discussing strategies and Maynard's fragile morale.

With Maynard's extradition and Raddatz's resignation from his position at Rowohlt, contact between Baldwin and Raddatz lost intensity during the early 1970s, but became more regular again when Raddatz was appointed head of feuilleton for Die Zeit in 1977. As he was determined to realize his objectives from the Rowohlt years through the newly acquired means of a newspaper, Raddatz turned to Baldwin as one of several acquaintances whom he tried to get involved in Die Zeit's literary and arts sections. His efforts were most effective in 1977 and 1978 , when Baldwin collaborated with him on at least three completed and several uncompleted projects. The earliest never completed project has left its only trace 
in a telegram sent presumably in 1976, with Raddatz asking if Baldwin was interested in interviewing the newly elected President Carter for Die Zeit. ${ }^{31}$ Although this idea was never realized, it may have been the trigger for a second project that soon followed. In March 1977, Raddatz proposed that Die Zeit reprint Baldwin's "Open Letter to Mr. Carter" that had recently been published in the New York Times. ${ }^{32}$ With Raddatz as translator, Die Zeit published this letter a few weeks later, and it found, as Raddatz puts it, "wide interest [...] with the German reading public."33

As soon as this project reached completion, Raddatz wrote to Baldwin about plans for further collaborations. While his idea of having Baldwin write an analysis of the first hundred days of Carter's presidency remained unrealized, another proposition was carried through. In March 1977, Raddatz wrote Baldwin:

Would you be interested in reviewing "Roots" for me? You know of course about the sensational reaction to the TV movie in the US. Meanwhile the book has been published and is also a big success in America. In spite of the fact that I am usually not printing reviews about books which are not yet published in Germany, I find the idea to print a review by James Baldwin about this book quite fascinating. So I would rather make an exception. ${ }^{34}$

The correspondence on this project shows that it required some persistence on Raddatz's part to secure Baldwin's participation. ${ }^{35}$ But he was ultimately successful. Raddatz's estate includes a five-page typescript entitled "Roots, and the Reichstag Fire and the Promised Land," in which Baldwin uses the opportunity to present Roots to a German audience to elaborate on the relation between history and identity, and to point to the connections between "niggers" and "foreign workers," and Germany's Nazi past and the Middle Passage. While the English original of this essay remains unpublished, the German version was published in December $1977 .^{36}$

Probably the most interesting collaboration between Raddatz and Baldwin was realized in 1978, when Raddatz came to Saint-Paul de Vence to conduct a long interview with the African-American writer. Although it was never published in English, the range of questions discussed can easily be put in relation to similar documents of the period. It presents Baldwin as deeply disillusioned about the degree of violence and the possibility of change in America-and yet it shows him as someone who sees it as his mission to remain in a contradictory state of hope: "I am a snake with two heads, but one stomach. I am an American Negro writer-I live a hope against my better knowledge." ${ }^{37}$ The position of Raddatz in this interview is quite interesting. While both he and Baldwin use their long acquaintanceship and the "anti-Nazi" Raddatz's German background to draw comparisons relating to the climate of "everyday fascism" in Germany, Raddatz at times takes the role of devil's advocate and critically questions Baldwin's "sentimentality" and his "exaggerations." 38 This strategy is quite effective: in response, Baldwin often finds particularly illustrative examples that catch the complexity of 
his thoughts. Maybe it is this quality of the interview that explains why Raddatz was not the only one to consider it an especially important accomplishment. While he reprinted it in his book of conversations with contemporary writers, his estate also contains documents regarding its reception: several letters to the editor as well as an edition of the Italian newspaper La Repubblica, which published the interview just three weeks after it had come out in Die Zeit. ${ }^{39}$

While there are no indications of further collaborations or intense correspondence after 1978, Baldwin and his work continued to be an important presence in Raddatz's own writings. ${ }^{40}$ In his 1980 collection of essays Eros und Tod, he included an updated and substantially expanded version of his essay from 1965. In several of his diaries-particularly in his "Pariser Tagebuch" about an extended stay in Paris that coincided with the news of Baldwin's death-Raddatz remembers Baldwin as "a good, close, even emphatic friend, with and for whom I fought some battles." 41 Moreover, in numerous texts on other writers and intellectuals, he is eager to draw connections to Baldwin's works, for example when he mentions him in a 1992 conversation with Nadine Gordimer, or when he begins his 1998 interview with Toni Morrison by asking about her relation to Baldwin. ${ }^{42}$ Finally, Raddatz chose the African-American writer as a subject in one of his last journalistic texts. His 2014 article for Die Zeit draws a line from Baldwin's early essays to Obama's presidency; it is both a recollection of "one of the most gifted American writers" and an attempt to reintroduce his works to an audience that, after a decade of popularity throughout the 1960s, has been quick to forget the unique "pearls" produced by a writer, who, just as a hurt pearl oyster, "never healed from his injuries." 43

\section{Raddatz's Reception of Baldwin's Works}

From the perspective of Baldwin scholarship, Raddatz's articles about the African-American writer are particularly interesting as examples of a relatively early, extensive reception that took place outside the US. As the title of his 1965 essay suggests, Raddatz was-unlike most of the US-based critics of the timeinitially most intrigued by the universal quality of Baldwin's writings. Conscious of the debates surrounding "Everybody's Protest Novel" and Baldwin's conviction about not wanting to be "merely a Negro writer," Raddatz introduces him as the author of psychological novels "in the exact sense of what this term means in a European, not an American tradition." ${ }^{44}$ Highlighting the linguistic and musical qualities, the lack of sentimentality, and the psychological precision of Baldwin's three published novels, Raddatz praises the writer's ability as creator of "roman[s] intérieur[s]," which use the example of African Americans to show how racial hatred transforms into self-hatred, self-alienation, and isolation. ${ }^{45}$

Interestingly, Raddatz's argument for the international relevance of Baldwin is more eager to emphasize the universality of "modern" experiences like selfalienation and lack of identity, than to relate his works more directly to specific topics relevant to postwar Germany. While the 1965 essay mentions possible 
parallels between the Third Reich and America only once, Raddatz-himself of bisexual orientation-almost completely dismisses Baldwin's treatment of homosexuality, which still constituted a crime in 1960s West Germany. Emphasizing that Giovanni's Room is by no means "merely the delicate miniature of a love between men," he interprets the characters of Baldwin's second novel as "white negroes" sharing the experiences of Baldwin's African-American protagonists. ${ }^{46}$ Essentially, Raddatz argues, they all suffer from a similar loneliness and lack of identity, which they try to momentarily flee by seeking sexual encounters and physical closeness to others. But, in Raddatz's words: "There is no happy person, no happy love in any of his novels. [...] It is his particularly frightening verdict that the human being becomes most clearly aware of his isolation when he tries to flee it-through sex." ${ }^{\prime 7}$

While the emphasis on Baldwin's treatment of 'universal' topics such as love and self-alienation remains consistent in many of Raddatz's later articles, a closer look at the revisions done for the 1980 version of his 1965 essay adds some interesting aspects to the overall picture. ${ }^{48}$ Most importantly, the conception of the book volume Eros and Tod is worth mentioning. Whereas American critics of the time tended to compare Baldwin to African-American writers such as Richard Wright and Ralph Ellison, Raddatz's volume of essays - and, similarly, the book version of the 1978 interview-puts his oeuvre in relation to the writings of Europeans such as Jean Genet, Jean-Paul Sartre, Josef Roth, and Christa Wolf. ${ }^{49}$ These writers share, in Raddatz's words, a number of "interior connections" rooted in their "joint experience of the world":

The writers reflected upon here had an encounter with the world that created: Horror. Panic. Fear. Flight.

If it is the hate of his own birth [...] or the play with one's death [...] -the radical beauty of these writers' works emanates from the radicalness of this: no.

This kind of literature is not one of fashionable denial, but one of the principle of despair. Literature without a home..$^{50}$

While Raddatz's categorization of Baldwin as part of an international vanguard of existentialist and politically subversive writers strengthens his emphasis on the universal relevance and the "human" quality of Baldwin's works, the chapter exclusively dedicated to the African-American writer is also noteworthy for something else. In more detail than in the 1965 version, Raddatz informs his readers of the social, political, and cultural factors necessary for contextualizing Baldwin's writings. Dwelling on the perception of African-American literature as "protest literature," on the recent contributions of young African-American writers to the genres of drama and theater, and on Baldwin's relation to jazz, Raddatz provides a more accurate depiction of the particular experiences that shaped his perception of the world.

In addition to his non-fictional writings directly about Baldwin, Raddatz mentions the African-American writer in various passages of his journalistic, 
autobiographical, and fictional works on other topics. While many of these instances fit with the analyses provided above, other examples are less anxious to argue for the universal relevance and psychological depth of Baldwin's writings. Rather than with the qualities of his works, these examples are typically concerned with Baldwin's persona, and with the many combats that Raddatz remembered fighting for him. Although it is striking that the Maynard case is not mentioned even once, Raddatz undoubtedly finds joy in depicting himself as part of an international group of left-wing intellectuals important enough to include a person as fascinating as Baldwin. But even when, as in the following episode from a work of fiction, Baldwin is presented as part of a cheerful cocktail party, there is often an indication of a more serious element within the generally anecdotal, light-hearted tone of the narration:

The guests moved through the three interconnected rooms as if they were following the orders of an invisible stage director, there was no served dinner, people helped themselves to the buffet arranged below a mosaic of peacocks, a waiter-the hands in white gloves-refilled the drinks. In the room in the back [...] a quarrel had started. Bernd could only hear pieces, the man from the authorities interrupted the black New Yorker in his cuttingly perfect English, they seemed to be discussing Wohltat's "you," illegal work, and travel through Nazi Germany. Klappen-Hugo [...] told of the permanent danger of being discovered during courier trips from Amsterdam to Berlin, Bernd heard the angry-defensive exclamation of the black American, "I couldn't have done that." 51

\section{The German Part of the Tony Maynard Experience}

The six months of Tony Maynard's imprisonment in Hamburg constitute one of the most important and memorable experiences that connected Baldwin and Raddatz. Maynard, a former bodyguard, chauffeur, and friend of Baldwin, was taken into custody in Hamburg in October 1967 when the United States charged him with the murder of a Marine in New York. He was extradited to the US in March 1968, and spent five more years in prison before his release. ${ }^{52}$ In recent Baldwin scholarship, Maynard's long and unjust imprisonment has come to be regarded as an event of major relevance for two shifts in Baldwin's writings of the 1970s and 1980s. First, its depiction in No Name has come to be seen as "only the beginning" of Baldwin's deep involvement with the prison experience that continues in works such as One Day When I Was Lost (1972) and If Beale Street Could Talk (1974). ${ }^{53}$ Secondly, the international character of this case and its beginning in a German prison that was an actual site of murder in Nazi Germany functions as a "springboard" for a change of perspective in Baldwin's analysis of racism, which in the course of the 1970s develops into a more globally oriented critique that is particularly striking in its ability to draw "a parallel between Nazi Germany in the early 1930s and racist America in the early 1970s." 54

Despite the broad influence of Maynard's case on the last two decades of Baldwin's writings, scholars have only begun to investigate the relevant pas- 
sages of No Name in greater detail. Miller mentions two aspects that may have led Baldwin-after hearing of Maynard's arrest in Hamburg in October 1967to consider himself both capable of and obliged to help his wrongfully arrested friend. On the one hand, from his eight traumatic days spent in a Paris prison in 1949, Baldwin must have been well aware not only of the dehumanizing effects of all kinds of incarceration, but also of the particular challenges of being imprisoned in a country with a foreign language and-in Maynard's case-a dreadful history. ${ }^{55}$ This issue is clearly addressed in No Name:

I was frightened in a way very hard to describe. The fact that this was the fabled Germany of the Third Reich, and this was a German prison, certainly had something to do with it. I was not so much afraid to see him as I was afraid of what might have happened to him-in him-the way one feels when about to see a loved one who has encountered great misfortune. One does not know what is left of the person. ${ }^{56}$

On the other hand, Miller mentions Baldwin's growing awareness of the fact thatin order to effectively help someone in a situation as unfortunate as Maynard's-it was of paramount importance to understand the workings of the legal system and to "think like a trial lawyer." 57 Baldwin's acquaintance with the Rowohlt publishing house and his friendship with Raddatz may have been the main reason why he considered himself able to meet this requirement. In No Name, Baldwin depicts Raddatz as an aide who knew "what it means to be beaten in prison"-in other words, someone who, through his own encounters with the systems of power of Nazi Germany, the GDR, and the Federal Republic, was well aware of the psychological effects of incarceration. ${ }^{58} \mathrm{He}$ also highlights that the task of developing a strategy which "must be dictated by the laws of two different countries, and the psychology of two not so very different peoples" could only be performed thanks to "the really extraordinary cooperation of my German publishers" and his editor's capacities for "tricking" the prison rules and "smelling a rat." clearly distinguishes his depiction of Raddatz from white liberal characters such as Cass in Another Country and Parnell in Blues for Mister Charlie, who, as Miller observes, are guided by the naive belief "that one should entrust the legal system to mete out justice fairly." 60

What my research can further teach us about the German part of the Maynard case can be subdivided into two categories: first, I can complement Baldwin's depiction of the legal proceedings in Hamburg by some archival material on the course of the lawsuit; and secondly, I will provide some observations on his attempts to transform Maynard's experience into a more generally applicable metaphor. With regard to the former, it is interesting to note that Baldwin's narrative of the events in Hamburg mentions several facts which-to say the leastare highly unusual for a modern state under the rule of law. Maynard's prison in Holstenglacis is not only depicted as a space guided by numerous regulations which need to be disobeyed in the service of humanity; it is also described as a scene of violent crime: 
Someone had goofed in that prison, very badly; after this visit, heads surely rolled. Tony had been beaten, and beaten very hard; his cheekbones had disappeared and one of his eyes was crooked; he looked swollen above the neck, and he took down his shirt collar, presently, to show us the swelling on his shoulders. ${ }^{61}$

These noteworthy experiences were a topic of discussion in several letters written when Rowohlt was preparing No Name for publication in Germany in 1972. While none of them were written by Raddatz, these letters are insightful for their intention of verifying the truthfulness of Baldwin's account. With this aim, Rowohlt's new chief editor, Hans Georg Heepe, sent a rough translation of No Name to Maynard's former German lawyer, Herbert Hornung, and asked him of his own recollections of the events. As Heepe summarizes in his letter to a colleague, Hornung found Baldwin's depiction-including the scandalous beating-accurate in most instances, and he did not consider the book to contain anything that could become legally problematic. ${ }^{62}$ However, the final version of Eine Straße und kein Name (1973) shows that the Rowohlt employees used their additional research on the Maynard case to improve the accuracy of Baldwin's depiction in some minor regards. ${ }^{63}$ In the German version, Baldwin's laudatory description of Raddatz is somewhat weakened by deleting the (perhaps not literally correct) passage about him "know[ing] what it means to be beaten in prison," and by replacing the part about him being "an antiNazi German, who has the scars to prove it" with the phrase "an anti-Fascist courageous enough to admit it." 64 A sub-clause about Raddatz's "accidental" participation at the meeting with Maynard is added because Hornung feared that this section might otherwise cause people to accuse him of "smuggling" Raddatz into the prison illegally. ${ }^{65}$ Whereas the depiction of the beating itself is left unchanged, the passage about Raddatz "[suing] the German state" in reaction to it is adjusted, and now tells of him filing a complaint against Hamburg's Department of Corrections. ${ }^{66}$

While the archival material from Germany confirms the general truthfulness of Baldwin's account of the legal proceedings, critics have often noted another feature of No Name. They have emphasized how the Maynard case "carries the weight of being, to some extent, representative," and they have noted that Maynard serves as an inspiration for characters such as Fonny in If Beale Street Could Talk and the protagonist of the unfinished Upon My Soul. ${ }^{67}$ A closer look at the passages set in Germany is highly indicative of Baldwin's attempt to add a metaphorical level to his account. Although we know from Raddatz's diaries that he had already visited Hamburg on several occasions, Baldwin's description of the city does not mention these more cheerful experiences, and, instead, starts by emphasizing Hamburg's coldness, its similarity to London, and the haunting presence of history: "Hamburg was frosty and dry as a bone, and blinding with ice and snow; and the sun, which never came to London, loitered in Hamburg all day long: über alles." 68 The association with Nazi Germany, which is also evoked through the description of the violent prison warders and the "intimidating" prison complex, 
is, in fact, an important factor for the creation of coherence between this part of Baldwin's account and other narrative strands. ${ }^{69}$

Whereas the Maynard case leads Baldwin to a prison that confronted him with the cruelty of Nazi Germany, other parts of No Name refer to the Holocaust by way of analogy. Baldwin, for example, suggests a parallel between McCarthy and Hitler; he reflects on the "Little Rock Nine" by comparing them to "small Jewish boys and girls, in Hitler's Germany"; he juxtaposes the behavior of "citizens [who] know nothing, and wish to know nothing" to "the Germans at the time of the Third Reich"; he describes Huey P. Newton in prison as "standing in the shadow of the gas chamber"; and he admits to beginning to think of the United States as "the Fourth Reich".$^{70}$ This partial list is, on the one hand, part of a "multidirectional" strategy of using "the presence of widespread Holocaust consciousness as a platform to articulate a vision of American racism past and present." ${ }^{71}$ On the other hand, Baldwin's decision to refer to Nazi Germany in No Name as both an actual setting and an analogy for a corrupted state power can be seen as something else. It signals a shift in his perspective, which is no longer preoccupied with interpreting racism along the lines of a "strategic American exceptionalism," but now attempts "to trace sexual and racial symmetries in the social spaces of the South, in the nation at large, and in the wider Western world." 72 In Baldwin's own words: "What's happening in America was clear to me many years ago, and to many people. Now we can only wait until we see what happens on the other side of the holocaust. It's not American, by the way, it's global." ${ }^{\text {73 }}$

\section{"Unruhestifter"/Disturbers of the Peace}

Another way to describe this crucial development in Baldwin's writings after the late 1960s would be to say that he eventually came to understand his vocation of being a "disturber of the peace" in a global sense. ${ }^{74}$ The image of disturbing the peace, which Baldwin and Raddatz both frequently use to emphasize their sense of mission, is, perhaps, also the most concise way of describing, by way of conclusion, what Baldwin scholarship can learn from his connection to Raddatz. In his German editor, Baldwin encountered a man who-just like himself-traced his decision to lead a life characterized "by more disquietude, less security" back to the "scars" accumulated in his family of origin and the oppressive climate of his home country. ${ }^{75}$ Their similarity of biographical experiences may have been the trigger for their commitment to a long-lasting dialogue that made them particularly capable of recognizing the connections between them. In this sense, Baldwin, already in 1967, closes a long letter to his German editor by saying: "I am feeling the way many Germans must have felt, many years ago." ${ }^{.76}$ In the same sense, Raddatz, already in 1965, was keen to emphasize the "universality" of Baldwin's writing and to promote a strategy of reception that would prevent his German readers from finding any false comfort in the fact that racism, in Baldwin's books, is committed on the other side of the Atlantic. With the Maynard case and Baldwin's growing disappointment with developments in the US, the ongoing dialogue with 
Raddatz may have been a major influence on his shift to a more global analysis of racism. Their conversations and collaborations may have equipped Baldwin with insights that explain why his writings after the early 1970s frequently point to what might be called the most disturbing analogy available-the one to Nazi Germany. However, the unique kinship which connected these two men could also explain something else: the fact that-in two of Baldwin's unpublished texts with strong references to Nazi Germany-the African-American characters not only encounter former Nazis on the other side of the Atlantic, but they also make at least one good friend. ${ }^{77}$

\section{Notes}

This article has profited from the inclusion of unpublished, archival material. For their support in providing this material and granting permission to use it, the author would like to express her gratitude to Eileen Ahearn from James Baldwin's estate, Heidi Buschhaus at Deutsches Literaturarchiv Marbach, Joachim Kersten from Fritz Raddatz's estate, and Christa Loose-Heepe. All translations from Fritz Raddatz's German publications are the author's own.

1 James Baldwin, No Name in the Street, in Collected Essays, ed. Toni Morrison (New York, Library of America, 1998), p. 423.

2 Magdalena Zaborowska, James Baldwin's Turkish Decade: Erotics of Exile (Durham, N.C., Duke University Press, 2009), p. 201.

3 Fritz Raddatz, "Schwarz ist die Farbe der Einsamkeit-Skizze zu einem Porträt James Baldwins," Frankfurter Hefte, 20:1 (1965), pp. 44-52; Fritz Raddatz, “Ich lebe eine Hoffnung wider besseres Wissen.' Ein ZEIT-Gespräch mit James Baldwin,” Die Zeit, 3 March 1978, http://pdf.zeit.de/1978/10/ich-lebe-eine-hoffnung-wider-besseres-wissen.pdf (accessed 21 June 2017). This interview was also published in the first volume of a series of conversations between Raddatz and writers of the period: Fritz Raddatz, "Ich lebe eine Hoffnung wider besseres Wissen.' Gespräch mit James Baldwin,” in Raddatz, ZEIT-Gespräche (Frankfurt/Main, Suhrkamp, 1978), pp. 113-22.

4 Fritz Raddatz, "Ich war ein lebendes Wunder," Die Zeit, 31 July 2014, http://pdf.zeit. de/2014/32/james-baldwin-rassismus-diskriminierung.pdf (accessed 21 June 2017).

5 Baldwin's image of himself as disturber of the peace resonates in various published conversations. In a 1961 interview, he discusses the idea that "artists are here to disturb the peace," and in 1973 he is quoted as saying "I also realized that to try to be a writer (which involves, after all, disturbing the peace) was political, whether one liked it or not; because if one is doing anything at all, one is trying to change the consciousness of other people." See Studs Terkel, “An Interview with James Baldwin," in Fred L. Standley and Louis H. Pratt (eds.), Conversations with James Baldwin (Jackson, MS, University Press of Mississippi, 1989), p. 21, and "The Black Scholar Interviews James Baldwin," in Standley and Pratt (eds.), Conversations with James Baldwin, p. 154. The phrase "disturber of the peace" is also used as a title in two other interviews. See Yvonne Neverson, "The Artist Has Always Been a Disturber of the Peace," in Standley and Pratt (eds.), Conversations with James Baldwin, pp. 168-71, and Eve Auchincloss and Nancy Lynch, "Disturber of the Peace: James Baldwin-An Interview," in Standley and Pratt (eds.), Conversations with James Baldwin, pp. 64-82. Similar to Baldwin's preference for the 
image of disturbing the peace, Raddatz used to characterize himself as "Unruhestifter." Literally translated, "Unruhestifter" means "creator of disquiet" or "troublemaker." For Raddatz's autobiography of this title, see Fritz Raddatz, Unruhestifter. Erinnerungen (Berlin, LIST, 2005).

6 Baldwin, No Name, p. 423.

7 See D. Quentin Miller, A Criminal Power: James Baldwin and the Law (Columbus, $\mathrm{OH}$, Ohio State University Press, 2012), p. 9.

8 The circumstances of Raddatz's complicated family background are not entirely clear from his own writings and public statements. I am grateful to Joachim Kersten for clarifying them.

9 Raddatz speculated about the influence of being a 'bastard' in an interview. See Sven Michaelsen, "Gedanken an den Tod vergällen das Leben nicht, sie intensivieren es," Süddeutsche Zeitung Magazin, 4 (2014), http://sz-magazin.sueddeutsche.de/texte/ anzeigen/41802 (accessed 21 June 2017); Raddatz, Unruhestifter, p. 12.

10 Raddatz, Unruhestifter, pp. 14, 17-18.

11 Ibid., p. 50.

12 Ibid., p. 49.

13 Ibid., pp. 48, 54.

14 Ibid., p. 51.

15 Michaelsen, "Gedanken an den Tod."

16 I have not been able to find out with certainty if Raddatz was incarcerated. His autobiography and his diaries do mention frequent interrogations by the Ministry of State Security and a growing fear of being imprisoned, but they do not describe an actual imprisonment. However, the autobiography contains one episode describing how Raddatz, after the fall of the Berlin Wall, felt a need to drive through East Berlin in his Porsche, and it explicitly mentions driving past "the Stasi prison in which I vanished, or the university or my former publishing house-the places where I was humiliated, insulted, also incarcerated" (Raddatz, Unruhestifter, p. 455). Similarly, the fictional protagonist of Raddatz's partly autobiographical trilogy is imprisoned in the GDR for ten days, before he finally decides to move back to West Germany. See Fritz Raddatz, Eine Erziehung in Deutschland (Reinbek, Rowohlt, 2006), pp. 308-14.

17 Fritz Raddatz, Tagebücher. 2002-2012 (Reinbek, Rowohlt, 2014), p. 426.

18 Ibid., pp. 426, 349; Raddatz, Unruhestifter, p. 209.

19 In 1969, Rowohlt-a publisher with a distinctly left-wing image-sold 50,000 copies of Yevgenia Ginzburg's book Marschroute eines Lebens on the Russian writer's experiences in Stalin's Gulag to the West German Ministry of Defense. Although both Ledig-Rowohlt and Raddatz had authorized this sale, they had neglected to investigate what the German Ministry would be doing with these books. Disguised as notebooks, they were distributed via balloons onto GDR territory, with a request printed in them that asked GDR citizens to get in touch with a West German address. Since this so-called "balloon affair" resulted in various complications and media attention, LedigRowohlt found it necessary to ask Raddatz to resign. See Fritz Raddatz, Jahre mit Ledig. Eine Erinnerung (Reinbek, Rowohlt, 2015), pp. 125-7; Dieter E. Zimmer, "Frißt die Revolution ihre Verleger? Unter- und Hintergründe einer Affäre im Hause Rowohlt," Die Zeit, 26 September 1969, http://pdf.zeit.de/1969/39/frisst-die-revolution-ihreverleger.pdf (accessed 21 June 2017).

20 Raddatz, Unruhestifter, p. 303. 
21 Ibid., p. 318.

22 Ibid., p. 369.

23 See Fritz Raddatz, Tagebücher. 1982-2001 (Reinbek, Rowohlt, 2010), and Raddatz, Tagebücher. 2002-2012.

24 The first quote is attributed to Frank Schirrmacher and appears on the dust-jacket of the first volume of Raddatz's diaries. For the second, see "Ein kaum erträgliches Kunstwerk," Cicero. Magazin für politische Kultur, 12 November 2010, www.cicero.de/ salon/ein-kaum-ertraegliches-kunstwerk/47217 (accessed 21 June 2017).

25 Raddatz, Unruhestifter, p. 385.

26 Baldwin's first books to be published in German were an essay collection entitled Schwarz und Weiß oder Was es heißt ein Amerikaner zu sein (literally "Black and White or What It Means to Be an American", a selection of essays from Notes of a Native Son and Nobody Knows My Name) and Giovanni's Room. Both appeared in 1963, quickly followed by Rowohlt's editions of The Fire Next Time (1964), Another Country (1965), and Go Tell It on the Mountain (1966). See Gianna Zocco, "Afroamerikanophilie' auf dem Buchmarkt? Die Literatur von James Baldwin im deutschsprachigen Raum," in Julia Danielczyk, Murray G. Hall, Christine Hermann, and Sandra Vlasta (eds.), Zurück in die Zukunft-Digitale Medien, historische Buchforschung und andere komparatistische Abenteuer (Wiesbaden, Harrassowitz, 2016), pp. 131-44.

27 During my visit to the German literary archive in Marbach - the holder of the Raddatz estate and the Rowohlt Publisher's archive-I was able to locate eleven letters and four brief notes or telegrams from Baldwin to Raddatz, and copies of sixteen letters and telegrams from Raddatz to Baldwin. Since the Raddatz papers are partly unsorted and not completely accessible, and since Baldwin's own estate is largely inaccessible, it is very likely that additional letters exist. Most of the letters I located date from the late 1960s and 1970s.

28 Deutsches Literaturarchiv Marbach (hereafter DLA), A:Raddatz, letters by James Baldwin to Fritz Raddatz, 4 January 1966; 9 May 1966; 17 July 1967; 2 October 1967.

29 Email to the author, 2 November 2016.

30 The first event is recounted several times in Raddatz's autobiographical writings. See Raddatz, Tagebücher. 1982-2001, pp. 61-2, 561, 660; Raddatz, Unruhestifter, p. 222. For the second event, see Raddatz, Tagebücher. 1982-2001, p. 455.

31 DLA, A:Raddatz, telegram by Fritz Raddatz to James Baldwin, presumably 1976.

32 See James Baldwin, “An Open Letter to Mr. Carter”, The New York Times, 23 January 1977, www.nytimes.com/books/98/03/29/specials/baldwin-carter.html (accessed 21 June 2017).

33 See James Baldwin, "Zu viele von uns sind eingesperrt”, trans. Fritz J. Raddatz, Die Zeit, 25 March 1977, http://pdf.zeit.de/1977/13/zu-viele-von-uns-sind-eingesperrt.pdf (accessed 21 June 2017); DLA, A:Raddatz, letter by Fritz Raddatz to James Baldwin, 12 May 1977.

34 DLA, A:Raddatz, letter by Fritz Raddatz to James Baldwin, 17 March 1977.

35 Raddatz's telegrams on this matter illustrate his persistence and style. In September 1977, he sends a telegram saying: "Dear Jimmy, I should address this wire to Mr. Baldwin, most unreliable author of the world. Roots will be published in Germany next month. Could I expect your article within the next two weeks, please?" Six weeks later, he even risks a "politically incorrect" joke: "I am counting on you. Please try to be my reliable slave." Three weeks later, he finally wires: "Dear Jimmy thank you for an excel- 
lent text which will be published in the next issue." DLA, A:Raddatz, letters by Fritz Raddatz to James Baldwin, 23 September 1977; 4 November 1977; and 22 November 1977.

36 The English version has not been reprinted in any of the existing collections of Baldwin's essays. However, The Price of the Ticket includes a review of Roots that is identical with a 1976 article for the New York Times, but differs from the longer typescript in Marbach. See James Baldwin, "A Review of Roots", in The Price of the Ticket (New York, St. Martin's Press, 1985), pp. 555-6. For the German version, see James Baldwin, "Wir brauchen ein Eden. Ein Buch, ein Film, ein Welterfolg" (literally: "We Need an Eden. A Book, a Film, a World Success"), Die Zeit, 9 December 1977, http:// pdf.zeit.de/1977/50/wir-brauchen-ein-eden.pdf (accessed 21 June 2017).

37 Baldwin relates the image of the snake to his conversation with Margaret Mead. See Raddatz, "Ich lebe eine Hoffnung" (book version), p. 122.

38 In the interview, Baldwin explicitly calls Raddatz an "anti-Nazi”, thereby repeating his phrase from No Name. Ibid., p. 116.

39 See Fritz Raddatz, "Ecco i miei assassini," La Repubblica, 21 March 1978.

40 The only document I have located from this period is a telegram from 1984, congratulating Baldwin on his sixtieth birthday. DLA, A:Raddatz, telegram by Fritz Raddatz to James Baldwin, 1 August 1984.

41 Raddatz, Tagebücher. 1982-2001, p. 209. Raddatz's Parisian diary is part of volume one of his published diaries. In 1988, it was also published separately by Die Zeit, and came out in four parts between 26 February and 18 March 1988.

42 See Fritz Raddatz, "Ein ZEIT-Gespräch mit der südafrikanischen Schriftstellerin und Nobelpreisträgerin Nadine Gordimer: Ich bin nicht liberal-ich bin radikal," Die Zeit, 29 May 1992, http://pdf.zeit.de/1992/23/ich-bin-nicht-liberal-ich-bin-radikal.pdf (accessed 21 June 2017); Fritz Raddatz, "Ein ZEIT-Gespräch mit Toni Morrison: Ich bin keine Amerikanerin,” Die Zeit, 12 February 1998, http://pdf.zeit.de/1998/08/morrison.txt.19980212.xml.pdf (accessed 21 June 2017).

43 See Raddatz, "Ich war ein lebendes Wunder." Although most of Baldwin's writings appeared in German translation, they are now largely out of print and available only through antiquarian booksellers. The only exception is Giovanni's Room, which was recently republished as part of the series "Die Zeit-Bibliothek der verschwundenen Bücher" by publisher Eder \& Bach.

44 James Baldwin, Nobody Knows My Name, in Morrison (ed.), Collected Essays, p. 137; Raddatz, "Schwarz," p. 45.

45 Raddatz, "Schwarz," p. 45.

46 Ibid., pp. 49, 45.

47 Ibid., pp. 48-9.

48 In accordance with the 1965 essay, Raddatz presents his interpretation of Rufus as "a criminal out of lost identity" in the 1978 interview; he mentions Baldwin's lonely homelessness in an essay on the painter Paul Wunderlich; and he reflects on Baldwin's ability to express the inevitable relation between love and loneliness in his 2014 article. See Raddatz, "Ich lebe eine Hoffnung" (book version), p. 119; Fritz Raddatz, Stahlstiche. 33 Einreden aus 35 Jahren (Reinbek, Rowohlt, 2013), p. 135; and Raddatz, "Ich war ein lebendes Wunder."

49 Similarly, the book version of the interview presents Baldwin's thoughts along with Raddatz's conversations with Günter Grass, Rolf Hochhut, Alberto Moravia, Susan 
Sontag, and others. An advertisement emphasizes that the interviews share "the question of the responsibility of the writer in our times"; "Von Zeit-Mitarbeitern," Die Zeit, 27 October 1978, http://pdf.zeit.de/1978/44/von-zeit-mitarbeitern.pdf (accessed 21 June 2017).

50 Fritz Raddatz, Eros und Tod. Literarische Porträts (Hamburg, Albrecht Knaus, 1980), p. 9.

51 Raddatz, Eine Erziehung, pp. 449-59. The same episode is recounted in the 1978 interview and Raddatz refers to it in his conversation with Nadine Gordimer. See Raddatz, "Ich lebe eine Hoffnung" (book version), pp. 117-18, and Raddatz, "Ich bin nicht liberal."

52 See Lynn Orilla Scott, James Baldwin's Later Fiction: Witness to the Journey (East Lansing, MI, Michigan State University Press, 2002), p. 66.

53 Miller, A Criminal Power, p. 127.

54 Zaborowska, Baldwin's Turkish Decade, p. 201; Scott, James Baldwin's Later Fiction, p. 67. From 1933 to 1945, the Untersuchungshaftanstalt Hamburg at Holstenglacis 3 served as a detention center for thousands of people arrested on the grounds of "special laws." Almost 500 prisoners were executed in the prison courtyard by beheading. Today, several memorial plaques commemorate these events. See https://de.wikipedia.org/wiki/Untersuchungshaftanstalt_Hamburg\#Zentrale_Hinrichtungsst.C3.A4tte (accessed 21 June 2017) and http://denkmalhamburg.de/gedenktafeln-an-der-untersuchungshaftanstalt/ (accessed 21 June 2017).

55 See Miller, A Criminal Power, pp. 1-3.

56 Baldwin, No Name, p. 416.

57 Miller, A Criminal Power, p. 154.

58 Baldwin, No Name, p. 423.

59 Ibid., pp. 415, 422, 423.

60 Miller, A Criminal Power, p. 68.

61 Baldwin, No Name, p. 423.

62 DLA, A:Rowohlt-Verlag (Autorenkonvolut James Baldwin), letter by Hans Georg Heepe to Jürgen Manthey, 11 July 1972.

63 As Heepe's widow Christa Loose-Heepe remembers, these changes were approved by Baldwin in all cases (email to the author, 12 January 2017).

64 Baldwin, No Name, p. 423; James Baldwin, Eine Straße und kein Name (Reinbek, Rowohlt, 1973), p. 83.

65 DLA, A:Rowohlt-Verlag (Autorenkonvolut James Baldwin), letter by Hans Georg Heepe to Jürgen Manthey, 11 July 1972.

66 Baldwin; No Name, p. 424; Baldwin, Eine Straße, p. 84. At the DLA, I found a letter that Maynard received from the prosecutor regarding his complaint about the beatings. This letter, which finds the accusations unjustified, gives a detailed view of the authorities' perspective on the events. The use of truncheons against Maynard is justified by the need to prevent disturbance among the other prisoners and his physical resistance to any milder attempts to quieten him down. DLA, A:Rowohlt-Verlag (Autorenkonvolut James Baldwin), letter by Oberstaatsanwalt Neuenbrug to Tony Maynard, 28 February 1968.

67 Miller, A Criminal Power, p. 130; see Scott, Baldwin's Later Fiction, pp. 66-7; Schomburg Center, New York City, "James Baldwin Letters and Manuscripts" (Sc MG 278, folder 4), letter by James Baldwin to "Dear Jay," enclosed: rough notes on "Upon My Soul: 
The Case of Tony Maynard," 7 March 1975. According to Baldwin's outline for "Upon My Soul," this project was planned to give a more detailed account of Maynard's experience. Baldwin's notes list "Holstenglacis" as a setting or preliminary title of one of its planned chapters.

68 Baldwin, No Name, p. 414.

69 Ibid., p. 415.

70 Ibid., pp. 372, 389, 454, 461, 467. This list could be easily expanded to include Baldwin's other writings of the period. Baldwin discusses the analogy to Nazi Germany in several of the interviews collected by Standley and Pratt. See Auchincloss and Lynch, "Disturber of the Peace," pp. 68, 82; David Frost, "Are We on the Edge of Civil War?," pp. 96-7; Herbert R. Lottman, "It's Hard to Be James Baldwin,” pp. 110-12. Several of his unpublished projects-including Upon My Soul (see note 67), the play The Welcome Table, and the screenplay In the Cross, A Trembling Soul: The Inheritance-were also conceived to include a strong reference to Nazi Germany. See Schomburg Center, New York City, "The Welcome Table" (Sc MG 345), James Baldwin, typescript of "The Welcome Table." Harvard Film Archive, Cambridge, "Fontaine, Dick. Paper and Film Outtakes Collection" (hfa00004, box 13), James Baldwin, typescript of In the Cross, A Trembling Soul: The Inheritance, 1972.

71 Michael Rothberg, Multidirectional Memory. Remembering the Holocaust in the Age of Decolonization (Stanford, CA, Stanford University Press, 2009), p. 3.

72 Cheryl A. Wall, "Stranger at Home. James Baldwin on What It Means to Be an American," in Cora Kaplan and Bill Schwarz (eds.), James Baldwin: America and Beyond (Ann Arbor, MI, University of Michigan Press, 2011), p. 37; Zaborowska, Baldwin's Turkish Decade, p. 241.

73 Lottman, "It's Hard to Be James Baldwin," p. 110.

74 See note 5.

75 Raddatz, Unruhestifter, p. 527.

76 DLA, A:Raddatz, letter by James Baldwin to Fritz Raddatz, 17 July 1967.

77 I am referring to the character Rolfe, who becomes friends with Brigid in In the Cross, A Trembling Soul, and to Peter in The Welcome Table (see note 70).

\section{Works Cited}

Auchincloss, Eve, and Nancy Lynch, "Disturber of the Peace: James Baldwin-An Interview," in Fred L. Standley and Louis H. Pratt (eds.), Conversations with James Baldwin (Jackson, MS, University Press of Mississippi, 1989), pp. 64-82.

Baldwin, James, Eine Straße und kein Name (Reinbek, Rowohlt, 1973).

- Nobody Knows My Name, in Collected Essays, ed. Toni Morrison (New York, Library of America, 1998), pp. 135-283.

- No Name in the Street, in Collected Essays, ed. Toni Morrison (New York, Library of America, 1998), pp. 349-475.

"An Open Letter to Mr. Carter," The New York Times, 23 January 1977, www. nytimes.com/books/98/03/29/specials/baldwin-carter.html (accessed 21 June 2017).

"A Review of Roots", in The Price of the Ticket (New York, St. Martin's Press, 1985), pp. 555-6.

"Wir brauchen ein Eden. Ein Buch, ein Film, ein Welterfolg," Die Zeit, 9 December 1977, http://pdf.zeit.de/1977/50/wir-brauchen-ein-eden.pdf (accessed 21 June 2017). 
“Zu viele von uns sind eingesperrt," trans. Fritz J. Raddatz, Die Zeit, 25 March 1977, http://pdf.zeit.de/1977/13/zu-viele-von-uns-sind-eingesperrt.pdf (accessed 21 June 2017).

"The Black Scholar Interviews James Baldwin," in Fred L. Standley and Louis H. Pratt (eds.), Conversations with James Baldwin (Jackson, MS, University Press of Mississippi, 1989), pp. 142-58.

"Ein kaum erträgliches Kunstwerk," Cicero. Magazin für politische Kultur, 12 November 2010, http://www.cicero.de/salon/ein-kaum-ertraegliches-kunstwerk/47217 (accessed 21 June 2017).

Frost, David, “Are We on the Edge of Civil War?", in Fred L. Standley and Louis H. Pratt (eds.), Conversations with James Baldwin (Jackson, MS, University Press of Mississippi, 1989), pp. 96-7.

Lottman, Herbert R., "It's Hard to Be James Baldwin," in Fred L. Standley and Louis H. Pratt (eds.), Conversations with James Baldwin (Jackson, MS, University Press of Mississippi, 1989), pp. 108-12.

Michaelsen, Sven, "Gedanken an den Tod vergällen das Leben nicht, sie intensivieren es," Süddeutsche Zeitung Magazin, 4 (2014), http://sz-magazin.sueddeutsche.de/texte/anzeigen/41802 (accessed 21 June 2017).

Miller, D. Quentin, A Criminal Power: James Baldwin and the Law (Columbus, OH, Ohio State University Press, 2012).

Neverson, Yvonne, "The Artist Has Always Been a Disturber of the Peace," in Fred L. Standley and Louis H. Pratt (eds.), Conversations with James Baldwin (Jackson, MS, University Press of Mississippi, 1989), pp. 168-71.

Raddatz, Fritz, "Ecco i miei assassini,” La Repubblica, 21 March 1978.

"Ein ZEIT-Gespräch mit der südafrikanischen Schriftstellerin und Nobelpreisträgerin Nadine Gordimer: Ich bin nicht liberal-ich bin radikal,” Die Zeit, 29 May 1992, http://pdf.zeit.de/1992/23/ich-bin-nicht-liberal-ich-bin-radikal.pdf (accessed 21 June 2017).

_ “Ein ZEIT-Gespräch mit Toni Morrison: Ich bin keine Amerikanerin,” Die Zeit, 12 February 1998, http://pdf.zeit.de/1998/08/morrison.txt.19980212.xml.pdf (accessed 21 June 2017).

_ Eine Erziehung in Deutschland (Reinbek, Rowohlt, 2006).

_ Eros und Tod. Literarische Porträts (Hamburg, Albrecht Knaus, 1980).

“'Ich lebe eine Hoffnung wider besseres Wissen.' Ein ZEIT-Gespräch mit James

Baldwin,” Die Zeit, 3 March 1978, http://pdf.zeit.de/1978/10/ich-lebe-eine-hoffnungwider-besseres-wissen.pdf (accessed 21 June 2017).

_- _ “Ich lebe eine Hoffnung wider besseres Wissen.' Gespräch mit James Baldwin," in Fritz Raddatz, ZEIT-Gespräche (Frankfurt/Main, Suhrkamp, 1978), pp. 113-22.

“"Ich war ein lebendes Wunder," Die Zeit, 31 July 2014, http://pdf.zeit.de/2014/32/

james-baldwin-rassismus-diskriminierung.pdf (accessed 21 June 2017).

- Jahre mit Ledig. Eine Erinnerung (Reinbek, Rowohlt, 2015).

"Schwarz ist die Farbe der Einsamkeit-Skizze zu einem Porträt James Baldwins,"

Frankfurter Hefte, 20:1 (1965), pp. 44-52.

- Stahlstiche. 33 Einreden aus 35 Jahren (Reinbek, Rowohlt, 2013).

Tagebücher. 1982-2001 (Reinbek, Rowohlt, 2010).

Tagebücher. 2002-2012 (Reinbek, Rowohlt, 2014).

Unruhestifter. Erinnerungen (Berlin, LIST, 2005). 
Rothberg, Michael, Multidirectional Memory. Remembering the Holocaust in the Age of Decolonization (Stanford, CA, Stanford University Press, 2009).

Scott, Lynn Orilla, James Baldwin's Later Fiction: Witness to the Journey (East Lansing, MI, Michigan State University Press, 2002).

Standley, Fred L., and Louis H. Pratt (eds.), Conversations with James Baldwin (Jackson, MS, University Press of Mississippi, 1989).

Terkel, Studs, "An Interview with James Baldwin," in Fred L. Standley and Louis H. Pratt (eds.), Conversations with James Baldwin (Jackson, MS, University Press of Mississippi, 1989), pp. 3-23.

"Von Zeit-Mitarbeitern," Die Zeit, 27 October 1978, http://pdf.zeit.de/1978/44/ von-zeit-mitarbeitern.pdf (accessed 21 June 2017).

Wall, Cheryl A., "Stranger at Home. James Baldwin on What It Means to Be an American," in Cora Kaplan and Bill Schwarz (eds.), James Baldwin: America and Beyond (Ann Arbor, MI, University of Michigan Press, 2011), pp. 35-52.

Zaborowska, Magdalena, James Baldwin's Turkish Decade: Erotics of Exile (Durham, N.C., Duke University Press, 2009).

Zimmer, Dieter E., "Frißt die Revolution ihre Verleger? Unter- und Hintergründe einer Affäre im Hause Rowohlt," Die Zeit, 26 September 1969, http://pdf.zeit.de/1969/39/ frisst-die-revolution-ihre-verleger.pdf (accessed 21 June 2017).

Zocco, Gianna, “Afroamerikanophilie' auf dem Buchmarkt? Die Literatur von James Baldwin im deutschsprachigen Raum," in Julia Danielczyk, Murray G. Hall, Christine Hermann, and Sandra Vlasta (eds.), Zurück in die Zukunft-Digitale Medien, historische Buchforschung und andere komparatistische Abenteuer (Wiesbaden, Harrassowitz, 2016), pp. 131-44.

\section{Contributor's Biography}

Gianna Zocco is a University Assistant in the Department of Comparative Literature at the University of Vienna. Her work focuses on American (especially African-American) and German literature, with a particular interest on cultural concepts of space, imagology, intertextuality, reception studies, and theories of cosmopolitan memory in literature. Her $\mathrm{Ph} . \mathrm{D}$. thesis on the motif of the window as opening into the interior in contemporary literature was published by Weidler in 2014. She is currently working on a book project on the images and functions of the German-speaking region and its history in AfricanAmerican literature, for which she just spent a one-year period of research at Columbia University in New York City. She has been awarded several prizes and fellowships for her work, among them a DOC fellowship by the Austrian Academy of Sciences, a DOC Award by the University and the City of Vienna, and a Max Kade Postdoctoral Fellowship. Recent publications include articles on James Baldwin, Joshua Ferris, Arthur Koestler, the window in Austrian literature, and the reception of African-American literature in Germany. 